\title{
Chemoenzymatic synthesis of luliconazole mediated by lipases
}

\author{
Thiago de S. Fonseca, ${ }^{[a]}$ Lara D. Lima, ${ }^{[a]}$ Maria da C. F. de Oliveira, ${ }^{[a]}$ Telma L. G. de Lemos, ${ }^{[a]}$ Davila \\ Zampieri, ${ }^{[a]}$ Francesco Molinari ${ }^{[b]}$ and Marcos C. de Mattos ${ }^{*[a]}$
}

\begin{abstract}
A straightforward chemoenzymatic synthesis of luliconazole has been developed. The key step involved the preparation of the enantiomerically pure $\beta$-halohydrin (1S)-2-chloro-1-(2,4dichlorophenyl)-1-ethanol through kinetic resolution of the corresponding racemic acetate, via hydrolytic approach, mediated by lipase from Thermomyces lanuginosus or Novozym $435^{\circledR}$. This latter enzyme proved to be a robust biocatalyst in the kinetic resolution, leading to the (S)- $\beta$-halohydrin with high selectivity (e.e. > 99\%, E > 200 ) in just $15 \mathrm{~min}$, at $45^{\circ} \mathrm{C}$, and being reused for five-times with maintenance high values of both conversion and enantioselectivity. Subsequently, the (S)- $\beta$-halohydrin was subjected to a mesylation reaction and the mesylated derivative reacted with 1cyanomethylimidazole leading to luliconazole in $43 \%$ yield and enantiomeric excess $>99 \%$.
\end{abstract}

\section{Introduction}

Luliconazole $(\boldsymbol{R}-7)$, Scheme 1 , also chemically known as (-)(2E)-[(4R)-4-(2,4-dichlorophenyl)-1,3-dithiolan-2-ylidene] $(1 \mathrm{H}$ imidazol-1-yl)acetonitrile, is a pharmaceutically active substance marketed under the brand names Luzu $^{\circledR}$ (Valeant Pharmaceuticals North America) and Lulicon ${ }^{\circledR}$ (Pola Pharma), among others..$^{[1,2]}$ This drug has antifungal action, being used for the treatment of tinea pedis, popularly known as athlete's foot, in addition to the treatment against of both candidiasis and pityriasis. ${ }^{[3]}$ In vitro, $(\boldsymbol{R})-7$ is one of the most potent antifungal agents against filamentous fungi including dermatophytes. ${ }^{[4]}$ Luliconazole was developed in Japan and approved by Japanese health agencies in 2005. ${ }^{[4]}$ More recently, in 2013, the US FDA approved the $(R)-7$ for the treatment of tinea pedis interdigital, tinea cruris and tinea corporis caused by the microorganisms Trichophyton rubrum and Epidermophyton floccosum..$^{[5]}$ It is noteworthy that the stereoisomers of luliconazole, $(S, E)$ and/or Zisomers, are considered impurities and should be removed to obtain the enantiomerically pure active pharmaceutical ingredient $(R)-7 .{ }^{[1]}$ The antifungal action exhibited by $(R)-7$ resides in the fact that this substance inhibits the enzyme sterol $14 \alpha$-demethylase (CYP51), which participates in the key step of ergosterol

[a] T. S. Fonseca, Dr. L. D. Lima, M. C. F. de Oliveira, Prof. Dr. T. L. G. de Lemos, Prof. Dr. D. Zampieri, Prof. Dr. M. C. de Mattos, Prof. Dr. Department of Organic and Inorganic Chemistry

Laboratory of Biotechnlogy and Organic Synthesis (LABS)

Federal University of Ceara

Campus do Pici, Postal Box 6044, 60455-970, Fortaleza, CE. Brazil

E-mail: mcdmatto@ufc.br

[b] Prof. Dr. F. Molinari

Department of Food

Environmental and Nutritional Sciences (DEFENS)

University Of Milan

Via Mangigalli 25, 20133, Milan, Italy biosynthesis. ${ }^{[6]}$ The mechanism of inhibiton includes the coordination of one of the nitrogen atoms of the imidazole ring with the iron atom of the heme group of the enzyme. ${ }^{[6]}$

The syntheses of luliconazol have been reported envolving some chiral strategies, such as asymmetric induction in the presence of oxazaborolidines,,$^{[1,7]}$ dihydroxylation of Sharpless ${ }^{[7]}$ and chiral catalysts based on ruthenium, iridium or rhodium. ${ }^{[8]}$

Herein, we report an unprecedented approach to obtain luliconazole, consisting of a lipase mediated chemoenzymatic synthesis, which has the preparation of a chiral $\beta$-halohydrin intermediate as key step. The importance of the preparation of chiral $\beta$-halohydrins lies in the fact that they are intermediates in the synthesis of substances with high added value..$^{[9,10]}$

One of the methods used to obtain chiral $\beta$-halohydrins is the enzymatic kinetic resolution of the corresponding racemate mediated by lipases. ${ }^{[11]}$ There are some reports of the kinetic resolution of $\beta$-halohydrins containing aromatic ring moiety via the acylation reaction, as well as from their corresponding esters, via hydrolytic process. Several lipases have been used in both processes such as Pseudomonas fluorescens, ${ }^{[12,13,14]}$ Burkholderia cepacia, ${ }^{[15,16,17]}$ Candida antarctica type B (Novozym $\left.435^{\circledR}\right),{ }^{[13,18,19]}$ P. cepacia, ${ }^{[20,21,22,23,24]}$ C. rugosa, ${ }^{[21]}$ Pseudomonas $s p .{ }^{[25]}$ and $P$. aeruginosa. ${ }^{[26]}$ In some of these examples, the kinetic resolution was performed in the presence of ionic liquids ${ }^{[17,23]}$ or by dynamic kinetic resolution in the presence of ruthenium as racemization agent. ${ }^{[20,26]}$

Lipases (EC 3.1.1.3) are highlighted as one of the most used enzymes in synthesis of enantiomerically pure drugs since no cofactors are required and regio-, chemo- and enantioselectivities are observed in the resolution process of racemates. Since most of the drugs are chiral, it is important to know which of the stereoisomers has the desired biological activity. Thus, the patient receives only one dose of the active stereoisomer, avoiding the side effects caused by the undesired stereoisomer. Therefore, biocatalysis represents an alternative tool for the production of enantiomerically pure chiral drugs over conventional chemical processes. ${ }^{[27]}$

In this paper, we describe the chemoenzymatic synthesis of luliconazole $(\boldsymbol{R})-\mathbf{7}$, which had as key step the preparation of the chiral $\quad \beta$-halohydrin (1S)-2-chloro-1-(2,4-dichlorophenyl)-1ethanol ( $S$ )-2, via kinetic resolution of acetate rac-3, mediated by a lipase, Scheme 1. Our focus was to perform an optimization of the reactional conditions, including the enzymes recycling outcome.

\section{Results and Discussion}

The chemoenzymatic synthesis of luliconazole is depicted in Scheme 1. The key step was the kinetic enzymatic resolution of the racemic 2-chloro-1-(2,4-dichlorophenyl)ethyl acetate (rac-3), via a hydrolytic approach, mediated by a lipase. 


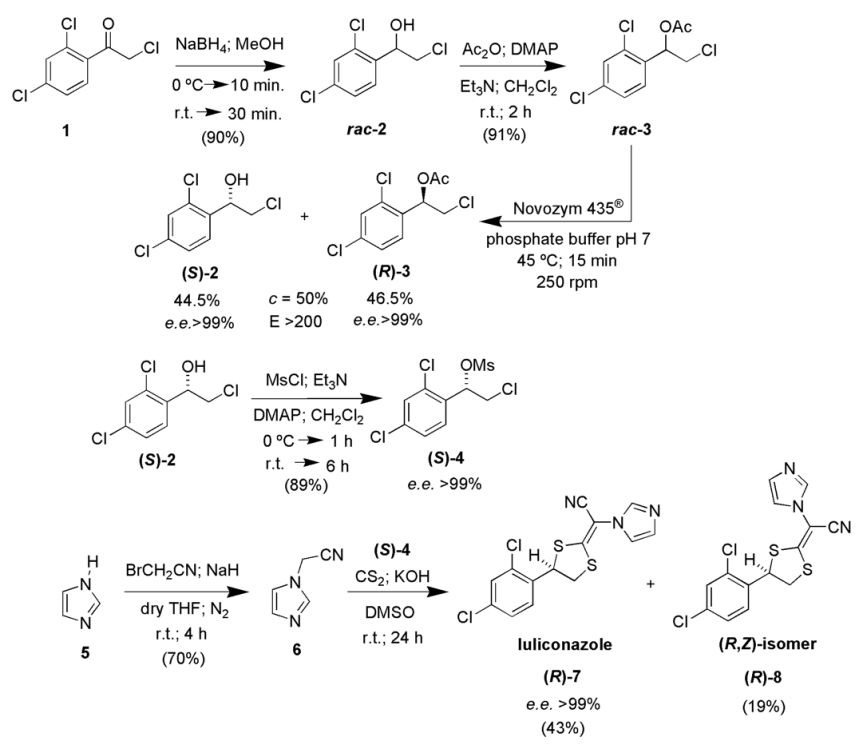

Scheme 1. Chemoenzymatic synthesis of Iuliconazole.

\section{Synthesis of racemic halohydrin (rac-2) and its acetate (rac-} 3)

As first step, the chemical reduction of the $\alpha$-chloroketone 1 was carried out by using sodium borohydride ( 0.5 eq.) in $\mathrm{MeOH}^{[28]}$ to yield rac-2 in $90 \%$ yield. Next, the chemical acetylation of rac2 was performed using $\mathrm{Ac}_{2} \mathrm{O}, \mathrm{DMAP}$ and $\mathrm{Et}_{3} \mathrm{~N}$ at room temperature for $2 \mathrm{~h}^{[29]}$ and allowed the preparation of rac-3 with $91 \%$ isolated yield, Scheme 1 . Adequate chiral GC analyses were developed for both rac-2 and rac-3 in order to achieve a reliable method to measure the enantiomeric excesses of both remaining substrate and the final product from the lipase-catalyzed resolution, Fig. 1.

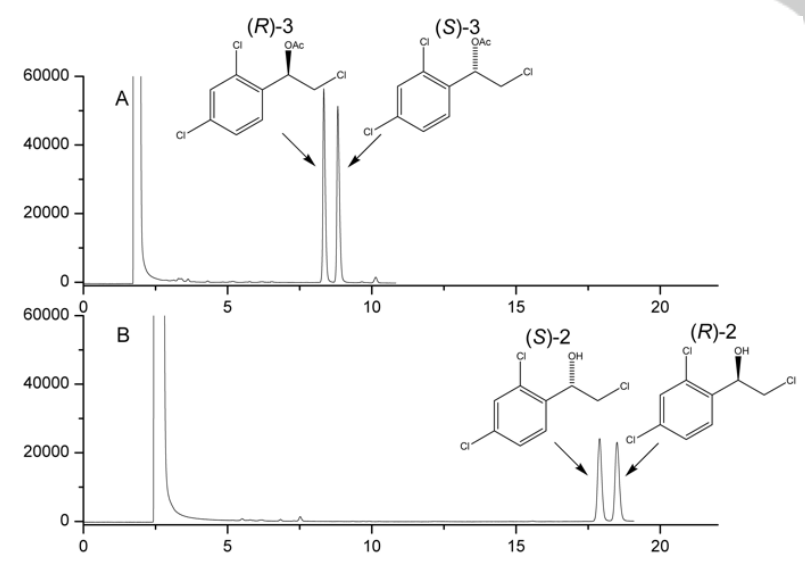

Figure 1. A) GC chromatogram of rac-2-chloro-1-(2,4-dichlorophenyl)ethyl acetate (rac-3: $\left.(R) t_{R} 8.33 \mathrm{~min} ;(S) t_{R} 8.82 \mathrm{~min}\right)$. B) GC chromatogram of rac-2chloro-1-(2,4-dichlorophenyl)1-ethanol (rac-2: (S) t 17.90 min.; $(R) t_{R} 18.50$ $\min )$.
Screening of lipase-mediated kinetic resolution of acetate rac-3 via hydrolysis

For initial screening of lipases, twelve commercially available enzymes (ratio 2:1 in weight respect to rac-3) were tried in the resolution of rac -3 at $30^{\circ} \mathrm{C}, 250$ r.p.m., phosphate buffer $\mathrm{pH} 7(0.1 \mathrm{M})$. Reactions were monitored for a maximum of $24 \mathrm{~h}$ and stopped before this time if the conversion had reached a value close to $50 \%$. The product $\beta$-halohydrin $(S)-2$ and the remaining acetate $(\boldsymbol{R})-\mathbf{3}$ were obtained, and the results are summarized in Table 1.

Table 1. Kinetic resolution of rac-3, via hydrolysis using lipases. ${ }^{a}$

\begin{tabular}{|c|c|c|c|c|c|c|}
\hline Entry & Lipase & $\begin{array}{l}\text { Time } \\
\text { (h) }\end{array}$ & $\begin{array}{l}\text { e.e.s } \\
(\%)^{b}\end{array}$ & $\begin{array}{l}\text { e.e.p } \\
(\%)^{b}\end{array}$ & $\begin{array}{l}\mathrm{c} \\
(\%)^{\mathrm{c}}\end{array}$ & $E^{d}$ \\
\hline 1 & P. fluorescens & 19 & 77 & 70 & 52 & 13 \\
\hline 2 & P. camemberti & 24 & 3 & 3 & 50 & 1 \\
\hline 3 & $\begin{array}{l}\text { R. miehei } \\
\text { immobilized on } \\
\text { anionic resin }\end{array}$ & 14 & 60 & 57 & 51 & 6 \\
\hline 4 & $\begin{array}{l}\text { Amano lipase } \\
\text { PS from B. } \\
\text { cepacia } \\
\text { immobilized on } \\
\text { diatomaceous } \\
\text { earth }\end{array}$ & 19 & 73 & 66 & 52 & 10 \\
\hline 5 & $\begin{array}{l}\text { Amano lipase } \\
\text { PS from } B . \\
\text { cepacia }\end{array}$ & 19 & 80 & 74 & 52 & 16 \\
\hline 6 & TLL $^{\mathrm{e}}$ & 24 & $>99$ & 92 & 52 & 128 \\
\hline 7 & Novozym $435^{\circledR}$ & 24 & 97 & 95 & 50 & 185 \\
\hline 8 & $\begin{array}{lr}\text { Amano } & \text { lipase } \\
\text { from } & M . \\
\text { javanicus } & \end{array}$ & 24 & 11 & 59 & 16 & 4 \\
\hline 9 & C. rugosa & 24 & 9 & 48 & 16 & 3 \\
\hline 10 & $\begin{array}{l}\text { Porcine } \\
\text { pancreas }\end{array}$ & 24 & 3 & 3 & 50 & 1 \\
\hline 11 & $R$. niveus & 24 & 1 & 64 & 2 & 5 \\
\hline 12 & $\begin{array}{l}\text { R. oryzae } \\
\text { immobilized on } \\
\text { immobead- } 150\end{array}$ & 19 & 53 & 57 & 48 & 6 \\
\hline
\end{tabular}

[a] Conditions: $30{ }^{\circ} \mathrm{C}$, lipase:rac-3 (2:1) at 250 r.p.m. [b] Determined by GC. [c] Conversion, $c=$ e.e.s $/($ e.e.s + e.e.p). [d] Enantiomeric ratio, $\mathrm{E}=\ln [1-\mathrm{c}(1+$ e.e.p $)] / \ln [1-c(1-$ e.e.p)]. [e] TLL: T. lanuginosus immobilized on immobead150

Among the lipases evaluated in the hydrolysis reaction of rac3. Thermomyces lanuginosus immobilized on immobead-150 (TLL) and CAL-B (Novozym $435^{\circledR}$ ) were the enzymes that provided better results. Conversions of 52 and $50 \%$, and $E$ values of 128 and 185 were observed, respectively, in $24 \mathrm{~h}$ of reaction 
(Table 1, entries 6 and 7). On the other hand, lipase from Rhizomucor miehei immobilized on anionic resin was the enzyme with the highest activity in the kinetic resolution of rac-3, with a conversion of $51 \%$ in only $14 \mathrm{~h}$, but with low selectivity ( $E$ value of 6), Table 1 entry 3. Lipase from Rhizopus niveus was the less active enzyme, leading to a conversion of only $2 \%$ in $24 \mathrm{~h}$ of reaction, (Table 1 , entry 11 ).

The remainder of the lipases evaluated, as $P$. fluorescens, Penicillium camemberti, Amano PS from B. cepacia immobilized on diatomaceous earth, Amano PS from B. cepacia, Amano lipase from Mucor javanicus, C. rugosa, porcine pancreas and Rhizopus oryzae immobilized on immobead-150, led to conversions of about $50 \%$, but with low enantioselectivity ( $E$ values ranging from 1 to 16 ; Table 1 entries $1,2,4,5,8,9,10$ and 12 , respectively).

\section{Improving the kinetic resolution of rac-3 through temperature variation}

In order to improve enzymatic resolution of rac-3, we performed a detailed study of the reaction condition, varying some parameters, such as temperature, reaction time and the ratio enzyme/substrate $(\mathrm{w} / \mathrm{w})$. For this study, we selected the enzymes TLL immobilized on immobead- 150 and Novozym $435^{\circledR}$ that were most promising in the kinetic resolution of rac-3 (Table 1, entries 6 and 7). In addition, since these two lipases are commercially immobilized, reuse studies have been performed.

In order to reduce the reaction time, the first variable to be changed was the temperature. With additions of $5^{\circ} \mathrm{C}$, the kinetic resolution of rac -3 was evaluated at 35,40 and $45^{\circ} \mathrm{C}$. The results were summarized in Table 2.

Table 2. Results of kinetic resolution of rac-3, via hydrolysis, mediated by lipases, varying temperature and enzyme/substrate ratio $(\mathrm{w} / \mathrm{w})$

\begin{tabular}{|c|c|c|c|c|c|c|c|}
\hline Entry & Lipase & $\mathrm{T}\left({ }^{\circ} \mathrm{C}\right)$ & $\begin{array}{l}\text { Time } \\
(\mathrm{min})\end{array}$ & $\begin{array}{l}\text { e.e.s } \\
(\%)^{\mathrm{a}}\end{array}$ & $\begin{array}{l}\text { e.e.p } \\
(\%)^{a}\end{array}$ & $\begin{array}{l}\mathrm{C} \\
(\%)^{\mathrm{b}}\end{array}$ & $\mathrm{E}^{\mathrm{c}}$ \\
\hline $1^{d}$ & $\begin{array}{l}\text { Novozym } \\
435^{\circledR}\end{array}$ & 35 & 960 & $>99$ & $>99$ & 50 & 200 \\
\hline $2^{d}$ & $\begin{array}{l}\text { Novozym } \\
435^{\circledR}\end{array}$ & 40 & 120 & $>99$ & $>99$ & 50 & $>200$ \\
\hline $3^{d}$ & $\begin{array}{l}\text { Novozym } \\
435^{\circledR}\end{array}$ & 45 & 15 & $>99$ & $>99$ & 50 & $>200$ \\
\hline $4^{e}$ & $\begin{array}{l}\text { Novozym } \\
435^{\circledR}\end{array}$ & 45 & 15 & $>99$ & $>99$ & 50 & $>200$ \\
\hline $5^{f}$ & $\begin{array}{l}\text { Novozym } \\
435^{\circledR}\end{array}$ & 45 & 15 & 76 & $>99$ & 43 & $>200$ \\
\hline $6^{d}$ & TLL $^{g}$ & 35 & 960 & 97 & 96 & 50 & $>200$ \\
\hline $7^{d}$ & TLL $^{g}$ & 40 & 120 & $>99$ & $>99$ & 50 & $>200$ \\
\hline $8^{d}$ & TLL $^{g}$ & 45 & 15 & $>99$ & $>99$ & 50 & $>200$ \\
\hline $9^{h}$ & TLL $^{\mathrm{g}}$ & 45 & 15 & $>99$ & $>99$ & 50 & $>200$ \\
\hline $10^{i}$ & TLL $^{g}$ & 45 & 15 & 41 & $>99$ & 30 & $>200$ \\
\hline
\end{tabular}

[a] Determined by GC. [b] Conversion, $c=$ e.e.s/(e.e.s + e.e.p). [c] Enantiomeric ratio, $\mathrm{E}=\ln [1-\mathrm{c}(1+$ e.e.p $)] / \ln [1-c(1-$ e.e.p $)]$. [d] lipase:rac-3 (2:1). [e] lipase:rac-3 (0.5:1). [f] lipase:rac-3 (0.25:1). [g] TLL: T. lanuginosus immobilized on immobead-150. [h] lipase:rac-3 (1.5:1). [i] lipase:rac-3 (1:1).
As we increased the temperature by $5{ }^{\circ} \mathrm{C}$ (from 30 to $35^{\circ} \mathrm{C}$ ), there was a decrease in reaction time from 24 to $16 \mathrm{~h}$ for both Novozym $435^{\circledR}$ and TLL enzymes, Table 2, entries 1 and 6. However, with Novozym $435^{\circledR}$ we observed an increase in the enantiomeric excess values for both product and remaining substrate (>99\%), Table 2 , entry 1 . No significant changes in the enantiomeric excess values of product and remaining substrate were observed for TLL, Table 2, entry 6 . On the other hand, the increment of $5{ }^{\circ} \mathrm{C}$ in the temperature (from 35 to $40{ }^{\circ} \mathrm{C}$ ) led to a significant decrease in reaction time from 16 to $2 \mathrm{~h}$ (Table 2, entries 2 and 7 ). In this case, both lipases yielded the product and the remaining substrate with enantiomeric excess $>99 \%$. A surprising result was obtained when the kinetic resolution was performed at $45^{\circ} \mathrm{C}$. At this temperature, the reaction time for an ideal kinetic resolution was only $15 \mathrm{~min}$ and both lipases led to the product and remaining substrate with enantiomeric excess $>99 \%$, conversion of $50 \%$ and $E$ value $>200$ (Table 2, entries 4 and 8 ).

Once the ideal temperature $\left(45^{\circ} \mathrm{C}\right)$ was determined, at which the kinetic resolution of rac-3 occurred in the shortest possible time (15 $\mathrm{min})$, we decided to evaluate the decrease of the loaded enzyme on the reaction.

\section{Effect of enzyme load in the kinetic resolution of rac-3}

For Novozym $435^{\circledR}$, the ratio enzyme:substrate was gradually decreased (from 2:1 to $0.25: 1$ ) and the kinetic resolution of rac-3 remained efficient up to 0.5:1 (w:w). Enantiomeric excess $>99 \%, 50 \%$ conversion and $E$ value $>200$ was observed for both product and substrate, Table 2, entry 4 . However, with an enzyme:substrate ratio of $0.25: 1$, the conversion had a slight decrease $(43 \%)$ leading to an enantiomeric excess of substrate remaining of $76 \%$, Table 2 , entry 5 . For TLL to maintain an optimal kinetic resolution of rac-3, the lowest enzyme:substrate ratio was $1.5: 1$, Table 2 , entry 9 . When we decreased the ratio to $1: 1$, the conversion showed a decrease $(30 \%)$ and the enantiomeric excess of the substrate was only $41 \%$, Table 2 , entry 10 .

Finally, since the most efficient enzymes (Novozym $435^{\circledR}$ and TLL) in the kinetic resolution of rac-3 are commercially immobilized, we decided to carry out a study of their reuse in ten reaction cycles.

\section{Reuse of the immobilized lipases}

This study was carried out in order to investigate the efficiency of Novozym $435^{\circledR}$ and TLL in maintaining satisfactory conversion and enantioselectivity values up to ten cycles of reuse (Fig. 2 and 3).

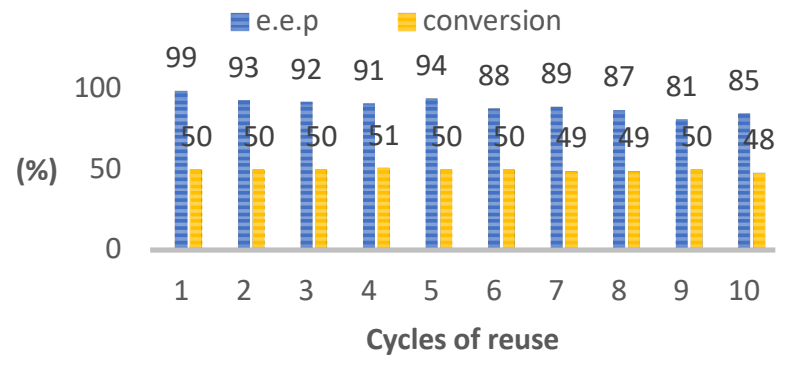

${ }^{a}$ Conditions: phosphate buffer $\mathrm{pH} 7(0.1 \mathrm{M}), 45^{\circ} \mathrm{C}$, lipase:rac-3a $(0.5: 1)$ and 15 $\min$ at $250 \mathrm{rpm}$.

Figure 2. Results from the reuse of Novozym $435^{\circledR}$. 


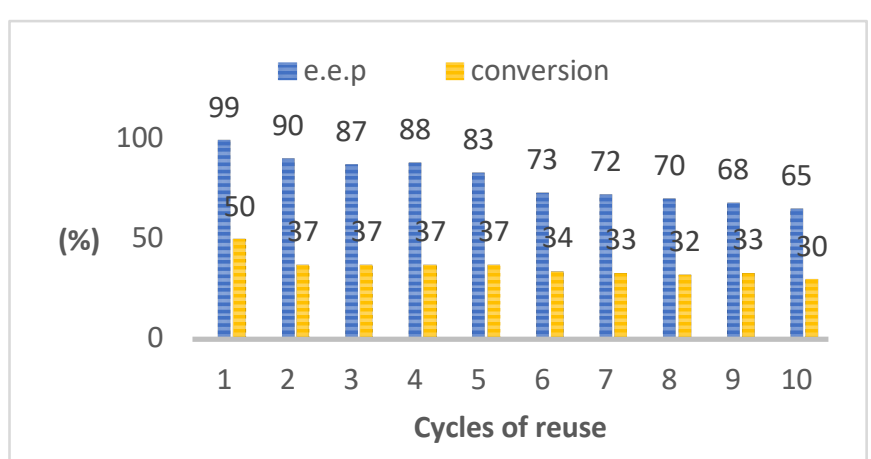

${ }^{a}$ Conditions: phosphate buffer $\mathrm{pH} 7(0.1 \mathrm{M}), 45^{\circ} \mathrm{C}$, lipase:rac-3a (1.5:1) and 15 $\min$ at $250 \mathrm{rpm}$.

Figure 3. Results from the reuse of TLL immobilized on immobead-150. ${ }^{\text {a }}$

Conversion values close to $50 \%$ were observed for Novozym $435^{\circledR}$ during ten reused cycles. Additionally, it was obtained enantiomeric excess values of product greater than $90 \%$ up to the fifth reaction cycle. From the sixth reaction cycle, the enzyme lost some of its selectivity, with enantiomeric excess values of product varying between 81 and $89 \%$ (Fig. 2).

When the reuse study was performed with TLL, it was verified that in the second reaction cycle the activity decreased to $37 \%$, a value that remained constant until the fifth reaction cycle. In the next reaction cycles, there was a slight decrease in the conversion values, culminating in a conversion of $30 \%$ in the last cycle. Concerning the selectivity, it was observed that the enantiomeric excess of the product decreased to $90 \%$ in the second reaction cycle and continued progressively decreasing until the tenth cycle at a value of $65 \%$ (Fig. 3 ).

Once the enzymatic loading and reuse studies were performed, it was possible to verify that Novozym $435^{\circledR}$ presented more advantages compared to TLL. In fact, Novozym $435^{\circledR}$ required a lower enzyme:substrate ratio (0.5:1) in detriment of 1.5:1 to TLL. Moreover, Novozym $435^{\circledR}$ can be reused in up to five reaction cycles maintaining high values of selectivity and conversion. On the other hand, in the presence of TLL, the conversion showed a considerable decrease already in the second reaction cycle, followed by a progressive decrease in the selectivity in the subsequent reaction cycles.

After optimizing the enzymatic kinetic resolution of $r a c-3$, we proceed with the following steps to obtain luliconazole $(\boldsymbol{R})-\mathbf{7}$.

\section{Synthesis of luliconazole $(R)-7$}

The kinetic resolution of rac-3 was performed under the optimized conditions (Scheme 1), phosphate buffer $(\mathrm{pH} 7)$, Novozym $435^{\circledR}$, enzyme:substrate $(0.5: 1), 45^{\circ} \mathrm{C}$ and $15 \mathrm{~min}$ of reaction, and provided the $\beta$-halohydrin (S)-2 and the remaining acetate $(\boldsymbol{R})-3$ with enantiomeric excess values $>99 \%$, conversion of $50 \%$ and enantioselectivity $(E)>200$.

Posteriorly, the (S)-2 was subjected to a mesylation reaction with $\mathrm{MsCl}$, DMAP, $\mathrm{Et}_{3} \mathrm{~N}$ in $\mathrm{CH}_{2} \mathrm{Cl}_{2}$ for $7 \mathrm{~h}$ to give the mesylated product $(S)-4$ in $89 \%$ yield and enantiomeric excess $>99 \%$, Scheme 1. ${ }^{[30]}$

Concomitantly, 1-cyanomethylimidazole 6 was obtained in $70 \%$ yield from the reaction of imidazole 5 with bromoacetonitrile, $\mathrm{NaH}$ in dry THF for $4 \mathrm{~h}$, Scheme $1 .^{[31]}$
Finally, in the last step, the mesylate (S)-4 was subjected to the reaction with 1-cyanomethylimidazole 6 in the presence of $\mathrm{CS}_{2}, \mathrm{~K}_{2} \mathrm{CO}_{3}$ in DMF, at room temperature and $24 \mathrm{~h}$ of reaction. ${ }^{[32]}$ However, under such conditions the substrate (S)-4 was recovered unchanged from the reaction medium. In search of better reaction conditions, we decided to use $\mathrm{KOH}$ as base and DMSO as the solvent. In this case, we obtained a mixture of the $E(\boldsymbol{R}-7)$ and $Z(\boldsymbol{R}-\mathbf{8})$ isomers in a ratio of 2:1. After purification, the luliconazole ( $E$-isomer) was obtained in $43 \%$ yield and enantiomeric excess $>99 \%$, Scheme $1^{[6]}$

\section{Conclusions}

In summary, we prepared luliconazole via an original approach involving the chemoenzymatic process using lipases. Both lipases TLL immobilized on immobead-150 and Novozym $435^{\circledR}$ were able to resolve the racemic 2-chloro-1-(2,4dichlorophenyl)ethyl acetate (rac-3) via a hydrolytic process. The enantiomerically pure key intermediate $\beta$-halohydrin (1S)-2chloro-1-(2,4-dichlorophenyl)-1-ethanol (S)-2 was obtained with conversion of $50 \%$ in only $15 \mathrm{~min}$ of reaction. Novozym $435^{\circledR}$ stood out as the best lipase because it required a lower enzymatic load enzyme:substrate (0.5:1) compared to TLL (1.5:1). Moreover, Novozym $435^{\circledR}$ proved to be a robust biocatalyst, since it could be reused in five reaction cycles, maintaining high values of both conversion and enantioselectivity. Finally, this unprecedented approach to obtain luliconazole can be considered eco-friendly, since a stable, low cost, reusable, commercially available and highly enantioselective biocatalyst was used.

\section{Experimental Section}

\section{Enzymes}

(i) Immobilized lipases: C. antarctica lipase type B immobilized on acrylic resin (CAL-B, Novozym 435, 7,300.0 U/g) and $R$. miehei lipase immobilized on anionic resin (RML, 150.0 $\mathrm{U} / \mathrm{g}$ ) were purchased from Novozymes ${ }^{\circledR}$. B. cepacia lipase immobilized on diatomaceous earth (Amano PS-IM, $\geq 500 \mathrm{U} / \mathrm{g}$ ), $T$. lanuginosus lipase immobilized on immobead-150 (TLL, 250.0 $\mathrm{U} / \mathrm{g}$ ) and $R$. oryzae lipase immobilized on immobead-150 (ROL, $340.0 \mathrm{U} / \mathrm{g}$ ) were acquired from Sigma-Aldrich $\circledast$. (ii) Crude lipase preparations: $M$. javanicus lipase (Amano $\mathrm{M}, \geq 10,000 \mathrm{U} / \mathrm{g}$ ), $R$. niveus lipase (RNL, $1,5 \mathrm{U} / \mathrm{mg}$ ), B. cepacia lipase (Amano PS, $\geq 30,000 \mathrm{U} / \mathrm{g}$ ), $P$. fluorescens lipase (AK, 22,100.0 U/g), $P$. camemberti lipase (Amano G, $50.0 \mathrm{U} / \mathrm{g}$ ) were acquired from Sigma-Aldrich ${ }^{\circledR}$. Porcine pancreas lipase (PPL, $46.0 \mathrm{U} / \mathrm{g}$ solid), and $C$. rugosa lipase $(\mathrm{CRL}, 1.4 \mathrm{U} / \mathrm{g}$ ) were obtained from SigmaAldrich ${ }^{2}$.

\section{Chemical Materials}

Chemical reagents were purchased from different commercial sources and used without further purification. Methanol, DMF, chloroform, DMSO, ethyl acetate and dichloromethane were acquired from Synth $\circledast$. Tetrahydrofuran and carbon disulfide were acquired from Sigma-Aldrich $®$. Solvents were distilled over an adequate desiccant under nitrogen. Analytical TLC analyses were performed on aluminum sheets pre-coated with silica gel 60 F254 (0.2 $\mathrm{mm}$ thick) from Merck $®$. Flash chromatographies were performed using silica gel 60 (230-240 mesh). 


\section{Analysis}

Melting points were determined in open capillary tube Microquímica model MQAPF-302 and are uncorrected. ${ }^{1} \mathrm{H}$ and ${ }^{13} \mathrm{C}$ NMR were obtained using Spectrometer Bruker model Avance DPX 300 , operating at frequency of $300 \mathrm{MHz}$ for hydrogen and frequency of $75 \mathrm{MHz}$ for carbon. The chemical shifts are given in delta $(\delta)$ values and the coupling constants $(J)$ in Hertz $(\mathrm{Hz})$. Measurement of the optical rotation was done in a Jasco P-2000 polarimeter. Gas chromatograph (GC) analyses were carried out in a Shimadzu chromatograph model GC 2010 with a flame ionization detector using a chiral column CP-chirasil$\operatorname{dex}\left(25 \mathrm{~m} \times 0.25 \mathrm{~mm} \times 0.25 \mu \mathrm{m}, 0.5\right.$ bar $\left.\mathrm{N}_{2}\right)$. For the following of the reaction time courses: rac-2-chloro-1-(2,4dichlorophenyl)ethyl acetate $($ rac -3$): 185^{\circ} \mathrm{C} ; 1^{\circ} \mathrm{C} / \mathrm{min} .190^{\circ} \mathrm{C}$ (hold $5 \mathrm{~min}$.); $0.5^{\circ} \mathrm{C} / \mathrm{min} .200^{\circ} \mathrm{C}$ (hold $15 \mathrm{~min}$.). Retention times were: $(R)$-acetate $=8.33 \mathrm{~min}$.; $(S)$-acetate $=8.82 \mathrm{~min}$. Haloydrin rac-2 was analyzed using a chiral column $\mathrm{Rt} \circledast \mathrm{bDEX}$ cst $(30 \mathrm{~m} \times$ $0.39 \mathrm{~mm} \times 0.25 \mu \mathrm{m}, 0.5$ bar $\mathrm{N}_{2}$ ). For the following of the reaction time courses: rac-2-chloro-1-(2,4-dichlorophenyl)ethanol (rac-2): $185^{\circ} \mathrm{C} ; 1^{\circ} \mathrm{C} / \mathrm{min} .190^{\circ} \mathrm{C}$ (hold $5 \mathrm{~min}$ ); $0.5^{\circ} \mathrm{C} / \mathrm{min} .200^{\circ} \mathrm{C}$ (hold $15 \mathrm{~min}$.). Retention times were: $(S)$-halohydrin= $17.90 \mathrm{~min}$.; $(R)$ halohydrin $=18.50 \mathrm{~min}$.

\section{Synthesis of rac- $\beta$-halohydrin (rac-2)}

A mass of 2-chloro-1-(2,4-dichlorophenyl)ethanone (1) (1 g $4.5 \mathrm{mmol})$ was dissolved in $\mathrm{MeOH}(40 \mathrm{~mL})$. Then, $\mathrm{NaBH}_{4}(0.085$ $\mathrm{g}, 2.2 \mathrm{mmol}$ ) of was added slowly at $0{ }^{\circ} \mathrm{C}$. The reaction was stirred for 30 min at room temperature. Upon completion, the $\mathrm{MeOH}$ was evaporated under reduced pressure. Then, $1 \mathrm{M} \mathrm{HCl}(10 \mathrm{~mL})$ of was added followed by extraction with EtOAc $(4 \times 60 \mathrm{~mL})$. Organic phases were combined and dried over anhydrous $\mathrm{Na}_{2} \mathrm{SO}_{4}$, filtered and solvent was evaporated under reduced pressure. Then, the crude product was purified by performing column chromatography, employing silica gel and $\mathrm{CHCl}_{3}$ to afford rac- $\beta$ halohydrin rac-2 in $90 \%$ yield $(0.913 \mathrm{~g}, 4.0 \mathrm{mmol})$.

\section{Synthesis of rac-acetate (rac-3)}

A suspension of DMAP $(0.054 \mathrm{~g}, 0.4 \mathrm{mmol})$ and acetic anhydride (1.25 mL, $13.3 \mathrm{mmol}$ ) was dissolved in $\mathrm{CH}_{2} \mathrm{Cl}_{2}(40 \mathrm{~mL})$. Then, rac-2 $(1 \mathrm{~g}, 4.4 \mathrm{mmol})$ and triethylamine $(616.3 \mu \mathrm{L}, 4.4$ $\mathrm{mmol}$ ) were added. The reaction was stirred for $2 \mathrm{~h}$ at room temperature. After this time, distilled water $(10 \mathrm{~mL})$ was added followed by extraction with $\mathrm{CH}_{2} \mathrm{Cl}_{2}(3 \times 50 \mathrm{~mL})$. The organic phases were combined and dried over anhydrous $\mathrm{Na}_{2} \mathrm{SO}_{4}$. Then, after filtration, the solvent was evaporated under reduced pressure and the crude product was purified using a silica gel column chromatography and $\mathrm{CHCl}_{3}$ to afford rac-acetate rac-3 in $91 \%$ yield $(1.071 \mathrm{~g}, 4.0 \mathrm{mmol})$.

\section{Synthesis of (1S)-2-chloro-1-(2,4-dichlorophenyl)-2- methanesulfonate (S-4)}

A mass of $(S)-2(0.5 \mathrm{~g}, 2.2 \mathrm{mmol})$ of was dissolved in $\mathrm{CH}_{2} \mathrm{Cl}_{2}$ $(25 \mathrm{~mL})$ at $0{ }^{\circ} \mathrm{C}$. Then, triethylamine $(307 \mu \mathrm{L}, 2.2 \mathrm{mmol})$, DMAP $(0.027 \mathrm{~g}, 0.2 \mathrm{mmol})$ and $\mathrm{MsCl}(855 \mu \mathrm{L}, 11.0 \mathrm{mmol})$ were added in $0{ }^{\circ} \mathrm{C}$ for $1 \mathrm{~h}$. Then, the reaction mixture was stirred at room temperature for $6 \mathrm{~h}$. After this time, $20 \mathrm{~mL}$ of distilled water was added followed by extraction with $\mathrm{CH}_{2} \mathrm{Cl}_{2}(3 \times 40 \mathrm{~mL})$. Then, the organic phase were combined and treated with saturated aqueous $\mathrm{NaHCO}_{3}$ solution $(20 \mathrm{~mL})$ and the organic phase was collected and dried with anhydrous $\mathrm{Na}_{2} \mathrm{SO}_{4}$. Finally, after filtration, the solvent was evaporated under reduced pressure and the crude product was purified using column chromatography with silica gel $\left(\mathrm{CHCl}_{3} /\right.$ hexane $\left.7: 3\right)$ to afford $(\boldsymbol{S})-4$ as yellow solid in $89 \%$ yield $(0.607 \mathrm{~g}, 2.0 \mathrm{mmol})$.

\section{Synthesis of 1-cyanomethylimidazole (6)}

To a solution of imidazole (5) $(0.5 \mathrm{~g}, 7.3 \mathrm{mmol})$ in dry THF $(50 \mathrm{~mL})$ under nitrogen atmosphere, $\mathrm{NaH}(0.176 \mathrm{~g}, 7.3 \mathrm{mmol})$ was added until complete release of hydrogen. After, bromoacetonitrile $(510 \mu \mathrm{L}, 7.3 \mathrm{mmol})$ was added dropwise, with the appearance of a yellow color in the reaction. The reaction mixture was stirred for $4 \mathrm{~h}$ at room temperature. Then, the solvent was evaporated under reduced pressure and distilled water (10 $\mathrm{mL}$ ) was added followed by extraction with $\mathrm{CH}_{2} \mathrm{Cl}_{2}(3 \times 50 \mathrm{~mL})$. The organic phase was dried over anhydrous $\mathrm{Na}_{2} \mathrm{SO}_{4}$. After filtration, the solvent was evaporated under reduced pressure. Then, the crude product was purified by performing column chromatography on silica gel $\left(\mathrm{CHCl}_{3} / \mathrm{MeOH} 9.5: 0.5\right)$ to afford (6) as a brown solid in $70 \%$ yield $(0.546 \mathrm{~g}, 5.1 \mathrm{mmol})$.

\section{Synthesis of luliconazole $(R-7)$}

A mass of $\mathrm{KOH}(0.210 \mathrm{mg}, 3.7 \mathrm{mmol})$ was dissolved in DMSO ( $3 \mathrm{~mL})$. Then, $6(0.1 \mathrm{~g}, 0.9 \mathrm{mmol})$ and carbon disulfide (56 $\mu \mathrm{L}, 0.9 \mathrm{mmol})$ in of DMSO $(3 \mathrm{~mL})$ at $4{ }^{\circ} \mathrm{C}$ were added. The reaction was stirred for $2 \mathrm{~h}$ at room temperature to form the dithiolate salt. Then, $(S)-4(0.560 \mathrm{~g}, 1.9 \mathrm{mmol})$ was added slowly at $4{ }^{\circ} \mathrm{C}$ and the reaction was stirred for $24 \mathrm{~h}$ at room temperature. After this time, cold water $(30 \mathrm{~mL})$ was added and the reaction mixture was stirred for $10 \mathrm{~min}$. Then, the product was extracted with EtOAc $(3 \times 40 \mathrm{~mL})$ and the organic phase were washed with ice water $(2 \times 20 \mathrm{~mL})$, dried over anhydrous $\mathrm{Na}_{2} \mathrm{SO}_{4}$, filtered and concentrated under reduced pressure. The crude product was purified using column chromatography with silica gel $\left(\mathrm{CHCl}_{3} / \mathrm{CH}_{3} \mathrm{CN}\right.$ 9:1) to afford the $(R, Z)$-isomer with $19 \%$ yield $(0.062 \mathrm{~g}, 0.18 \mathrm{mmol})$ and $(R)-7$ as yellow solid in $43 \%$ yield $(0.141$ $\mathrm{g}, 0.4 \mathrm{mmol})$.

General procedure for the lipase-catalyzed hydrolysis of rac3

A suspension of rac-3 $(0.030 \mathrm{~g}, 0.1 \mathrm{mmol})$ and lipase (ratio $2: 1$ in weight respect to the rac-3) in phosphate buffer $100 \mathrm{mM}$ $\mathrm{pH} 7.0(1.0 \mathrm{~mL})$ was shaken in their proper temperature and time reaction at $250 \mathrm{rpm}$. After the conversion reaches a value close to $50 \%$, the products were extracted with EtOAc $(3 \times 5 \mathrm{~mL})$. The organic phases were combined and dried over $\mathrm{Na}_{2} \mathrm{SO}_{4}$, filtered and the solvent evaporated under reduced pressure. The reaction crude was purified by flash chromatography on silica gel $(100 \%$ $\mathrm{CHCl}_{3}$ ), yielding $(R)$-acetate $(R-3)$ and $(S)$-halohydrin $(S-2)$ being their enantiomeric excess determined by GC.

\section{Synthesis of $(R)-3$ and $(S)-2$ mediated by Novozym $435^{\circledR}$}

A suspension of rac-3 $(0.5 \mathrm{~g}, 1.9 \mathrm{mmol})$ and $0.25 \mathrm{~g}$ of Novozym $435^{\circledR}$ in phosphate buffer $100 \mathrm{mM} \mathrm{pH} 7.0(19 \mathrm{~mL})$ was shaken in $45^{\circ} \mathrm{C}$ and $15 \mathrm{~min}$ at $250 \mathrm{rpm}$. After the conversion has reached a value close to or $50 \%$, the products were extracted with EtOAc $(3 \times 20 \mathrm{~mL})$. The organic phases were combined and dried over $\mathrm{Na}_{2} \mathrm{SO}_{4}$, filtered and the solvent evaporated under reduced pressure. The reaction crude was purified by flash chromatography on silica gel and $\mathrm{CHCl}_{3}$, yielding $46.5 \%$ of $(R)-$ acetate $(R-3)(0.454 \mathrm{~g}, 1.7 \mathrm{mmol})$ with $[\alpha]_{\mathrm{D}}^{23}=-52.3$ ( $c=1.0$ in ethyl acetate) for $99 \%$ e.e. and $44.5 \%$ of (S)-halohydrin (S-2) $(0.383 \mathrm{~g}$, $1.7 \mathrm{mmol})$ with $[\alpha]_{D}{ }^{20}=+51.1(c=2.50$ in chloroform) for $99 \%$ e.e.; Lit $[\alpha]_{D}{ }^{25}=-52.8(c=2.55$ in chloroform $)$ for $99 \%$ e.e. of the $(R)-$ enantiomer. ${ }^{[33]}$ 
rac-2-chloro-1-(2,4-dichlorophenyl)ethanol (rac-2): $90 \%$ yield. Orange solid. $R_{\mathrm{f}}=0.45\left(\mathrm{CHCl}_{3}\right)$; m.p. 47-49 C; Lit m.p. 46$47 \mathrm{C}$; [15] ${ }^{1} \mathrm{H}$ NMR $\left(300 \mathrm{MHz}, \mathrm{CDCl}_{3}, \mathrm{TMS}\right): \delta=2.50(\mathrm{br} \mathrm{s}, \mathrm{OH}, 1 \mathrm{H})$, 3.52 (dd, $J=11.8,5.0 \mathrm{~Hz}, 1 \mathrm{H}$ ), 3.87 (dd, J=8.3, $2.0 \mathrm{~Hz}, 1 \mathrm{H}$ ), 5.26 (dd, $J=6.0,2.7 \mathrm{~Hz}, 1 \mathrm{H}), 7.31$ (dd, $J=10.1,2.3 \mathrm{~Hz}, 1 \mathrm{H}), 7.38$ (d, $J=1.8 \mathrm{~Hz}, 1 \mathrm{H}), 7.57 \mathrm{ppm}(\mathrm{d}, J=8.0 \mathrm{~Hz}, 1 \mathrm{H}) ;{ }^{13} \mathrm{C} \mathrm{NMR}(75 \mathrm{MHz}$, $\left.\mathrm{CDCl}_{3}, \mathrm{TMS}\right): \delta=49.4\left(\mathrm{CH}_{2}\right), 70.5(\mathrm{CH}), 127.8(\mathrm{CH}), 128.7(\mathrm{CH})$, $129.5(\mathrm{CH}), 132.7(\mathrm{C}), 134.8(\mathrm{C}), 136.1 \mathrm{ppm}(\mathrm{C})$.

rac-2-chloro-1-(2,4-dichlorophenyl)ethyl acetate (rac-3): $91 \%$ yield. Yellow liquid. $R_{\mathrm{f}}=0.61\left(\mathrm{CHCl}_{3}\right) ;{ }^{1} \mathrm{H}$ NMR $(300 \mathrm{MHz}$, $\mathrm{CDCl}_{3}, \mathrm{TMS}$ ): $\delta=2.17(\mathrm{~s}, 3 \mathrm{H}), 3.72(\mathrm{dd}, J=11.8,4.9 \mathrm{~Hz}, 1 \mathrm{H}), 3.84$ (dd, J=11.8, 8.1 Hz, 1H), 6.31 (dd, $J=10.6,3.7 \mathrm{~Hz}, 1 \mathrm{H}), 7.28$ (dd, $J=10.5,2.1 \mathrm{~Hz}, 1 \mathrm{H}), 7.37$ (d, J=8.4 Hz, 1H), $7.40 \mathrm{ppm}(\mathrm{d}, J=1.9$ $\mathrm{Hz}, 1 \mathrm{H}) ;{ }^{13} \mathrm{C}$ NMR $\left(75 \mathrm{MHz}, \mathrm{CDCl}_{3}, \mathrm{TMS}\right): \delta=21.0\left(\mathrm{CH}_{3}\right), 45.2$ $\left(\mathrm{CH}_{2}\right), 71.4(\mathrm{CH}), 127.7(\mathrm{CH}), 128.9(\mathrm{CH}), 129.8(\mathrm{CH}), 133.2(\mathrm{C})$, 133.7 (C), 1353 (C), 169.6 ppm (C).

(S)-2-chloro-1-(2,4-dichlorophenyl)-2-methanesulfonate ( $S$ 4): $89 \%$ yield. Yellow solid. $R_{\mathrm{f}}=0.45\left(\mathrm{CHCl}_{3} /\right.$ hexane $\left.7: 3\right)$; m.p. 73$76 \mathrm{C} ;[\alpha]_{\mathrm{D}}{ }^{20}=+64.0$ (c=1.0 in chloroform) for $99 \%$ e.e.; ${ }^{1} \mathrm{H}$ NMR (300 MHz, $\mathrm{CDCl}_{3} \mathrm{TMS}$ ): $\delta=3.09$ (s, 3H), 3.75 (dd, $J=12.1,4.7 \mathrm{~Hz}$, $1 \mathrm{H})$, 3.84-3.87 (m, $1 \mathrm{H}) ; 6.05(\mathrm{dd}, J=9.3,3.5 \mathrm{~Hz}, 1 \mathrm{H}), 7.27-7.32$ $(\mathrm{m}, 1 \mathrm{H}), 7.34-7.38(\mathrm{~m}, 1 \mathrm{H}), 7.51-7.59 \mathrm{ppm}(\mathrm{m}, 1 \mathrm{H}) ;{ }^{13} \mathrm{C}$ NMR $(75$ $\left.\mathrm{MHz}, \mathrm{CDCl}_{3}, \mathrm{TMS}\right): \delta=38.9\left(\mathrm{CH}_{3}\right), 45.3\left(\mathrm{CH}_{2}\right), 78.7(\mathrm{CH}), 128.1$ $(\mathrm{CH}), 129.1(\mathrm{CH}), 129.9(\mathrm{CH}), 132.4(\mathrm{C}), 132.7(\mathrm{C}), 136.2 \mathrm{ppm}$ (C).

1-cyanomethylimidazole (6): $70 \%$ yield. Brown solid $R_{\mathrm{f}}=0.50\left(\mathrm{CHCl}_{3} / \mathrm{MeOH}\right.$ 9.5:0.5); m.p. 141-142 C; Lit m.p. $138 \mathrm{C}$; $[34]$ ${ }^{1} \mathrm{H}$ NMR $\left(300 \mathrm{MHz}, \mathrm{CDCl}_{3}, \mathrm{TMS}\right): \delta=4.92(\mathrm{~s}, 1 \mathrm{H}), 7.10(\mathrm{~s}, 1 \mathrm{H})$, 7.27 (s, 1H), $7.55 \mathrm{ppm}(\mathrm{s}, 1 \mathrm{H}) ;{ }^{13} \mathrm{C} \mathrm{NMR}\left(75 \mathrm{MHz}, \mathrm{CDCl}_{3}, \mathrm{TMS}\right)$ : $\delta=34.5\left(\mathrm{CH}_{2}\right), 113.8(\mathrm{C}), 119.1(\mathrm{CH}), 130.9(\mathrm{CH}), 137.2 \mathrm{ppm}$ $(\mathrm{CH})$.

$(R, Z)$-Isomer $(\boldsymbol{R}-8): \quad 19 \%$ yield. Yellow solid. $R_{\mathrm{f}}=0.41$ $\left(\mathrm{CHCl}_{3} / \mathrm{CH}_{3} \mathrm{CN}\right.$ 9:1); m.p. $113-115 \mathrm{C}$; ${ }^{1} \mathrm{H}$ NMR $\left(300 \mathrm{MHz}, \mathrm{CDCl}_{3}\right.$, TMS): $\delta=3.74$ (dd, $J=18.0,6.0 \mathrm{~Hz}, 1 \mathrm{H}$ ), 3.96 (dd, $J=15.0,3.0 \mathrm{~Hz}$, $1 \mathrm{H}), 5.63(\mathrm{dd}, J=15.0,6.0 \mathrm{~Hz}, 1 \mathrm{H}), 7.06(\mathrm{~s}, 1 \mathrm{H}), 7.17(\mathrm{~s}, 1 \mathrm{H}), 7.27-$ $7.33(\mathrm{~m}, 1 \mathrm{H}), 7.46(\mathrm{~d}, J=1.0 \mathrm{~Hz}, 1 \mathrm{H}), 7.52(\mathrm{~d}, J=9.0 \mathrm{~Hz}, 1 \mathrm{H}), 7.65$ ppm (s, $1 \mathrm{H}) ;{ }^{13} \mathrm{C}$ NMR $\left(75 \mathrm{MHz}, \mathrm{CDCl}_{3}, \mathrm{TMS}\right) \delta=44.2\left(\mathrm{CH}_{2}\right), 55.6$ $(\mathrm{CH}), 77.6(\mathrm{C}), 114.6(\mathrm{C}), 119.3(\mathrm{CH}), 128.1(\mathrm{CH}), 129.2(2 \mathrm{CH})$ $130.4(2 \mathrm{CH}), 131.4(\mathrm{C}), 134.4(\mathrm{C}), 136.1(\mathrm{C}), 137.2 \mathrm{ppm}(\mathrm{CH})$.

Luliconazole $(\boldsymbol{R}-7): 43 \%$ yield. Yellow solid. $R_{\mathrm{f}}=0.45$ $\left(\mathrm{CHCl}_{3} / \mathrm{CH}_{3} \mathrm{CN}\right.$ 9:1); m.p. $151-152$ C; Lit m.p. $151.1 \mathrm{C} ;{ }^{[35]}[\alpha]_{\mathrm{D}}{ }^{20}=-$ 50.7 ( $c=1.0$ in dimethylformamide) for $99 \%$ e.e.; ${ }^{1} \mathrm{H}$ NMR $(300$ $\mathrm{MHz}, \mathrm{CDCl}_{3}, \mathrm{TMS}$ ): $\delta=3.66$ (dd, $J=11.6,4.4 \mathrm{~Hz}, 1 \mathrm{H}$ ), 3.89 (dd, $J=10.3,3.1 \mathrm{~Hz}, 1 \mathrm{H}), 5.70(\mathrm{dd}, J=7.6,3.2 \mathrm{~Hz}, 1 \mathrm{H}), 7.06(\mathrm{~s}, 1 \mathrm{H})$, $7.19(\mathrm{~s}, 1 \mathrm{H}), 7.35$ (dd, J=6.1,1.1 Hz, 1H), $7.49(\mathrm{~d}, J=1.1 \mathrm{~Hz}, 1 \mathrm{H})$, 7.59 (d, J=5.0 Hz, 1H), $7.66 \mathrm{ppm}(\mathrm{s}, 1 \mathrm{H}) ;{ }^{13} \mathrm{C}$ NMR $(75 \mathrm{MHz}$, $\mathrm{CDCl}_{3}$, TMS) $\delta=42.8\left(\mathrm{CH}_{2}\right), 44.4(\mathrm{CH}), 77.4(\mathrm{C}), 114.7$ (C), 119.4 $(\mathrm{CH}), 128.2(\mathrm{CH}), 129.2(\mathrm{CH}), 130.3(2 \mathrm{CH}), 130.4(\mathrm{C}), 131.5(\mathrm{C})$, $134.4(\mathrm{CH}), 136.1(\mathrm{C}), 137.2 \mathrm{ppm}(\mathrm{C})$

\section{Acknowledgements}

The authors thank to the Fundação Cearense de Apoio ao Desenvolvimento Científico e Tecnológico (FUNCAP), Conselho Nacional de Desenvolvimento Científico e Tecnológico (CNPq) and Coordenação de Aperfeiçoamento de Ensino Superior (CAPES) for fellowships and financial support. The authors thank the Brazilian funding agency Conselho Nacional de Desenvolvimento Científico e Tecnológico (CNPq) for providing the Special Visiting Researcher fellowship (process 400171/2014-7) under the Brazilian Scientific Program "Ciência sem Fronteira" and the research sponsorships of M. C. de Mattos (Process: 308034/2015-5) and M. C. F. de Oliveira (Process:
303365/2014-5). The authors thank to the Northeastern Center for Application and Use of NMR (CENAUREMN) for NMR data.

\section{Conflict of interest}

The authors declare no conflict of interest.

Keywords: biocatalysis $\cdot$ chemoenzymatic synthesis $\cdot$ kinetic resolution • Iuliconazole $\cdot$ Novozym $435^{\circledR}$

[1] S. B. Bhirud, K. H. Bhushan, S. S. Zhope, S. G. Ghadigaonkar, P. Singh S. A. Deshmukh, P. Chand (Glenmark Pharmaceuticals Limited) WO 2016092478, 2016 [Chem. Abstr.].

[2] K. W.-Nakashima, N. Yamada, S. Morino, O. Yamamoto, Med. Mycol. 2015, 53, 860-867.

[3] a) H. Koga, Y. Nanjoh, H. Kaneda, H. Yamaguchi, R. Tsuboi, Antimicrob. Agents Chemother. 2012, 56, 3138-3143; b) H. Koga, Y. Nanjoh, K Makimura, R. Tsuboi, Med. Mycol. 2009, 47, 640-647.

[4] R. K. Scher, N. Nakamura, A. Tavakkol, Mycoses 2014, 57, 389-393.

[5] A. Mullard, Nat. Rev. Drug Discovery 2014, 13, 85-89.

[6] G. I. Lepesheva, R. D. Ott, T. Y. Hargrove, Y. Y. Kleshchenko, I. Schuster W. D. Nes, G. C. Hill, F. Villalta, M. R. Walterman, Chem Biol. 2007, 14 1283-1293.

[7] H. Kodama, Y. Niwano, K. Kanai, M. Yoshida (Nihon Nohyaku Co., Ltd.) WO 1997002821, 1997 [Chem. Abstr.].

[8] R. S. Vasconcelos (Libbs Farmacêutica Ltda) PI 11040742, 2011 [Chem. Abstr. ].

[9] G.-C. Xu, H.-L. Yu, Y.-P. Shang, J.-H. Xu, RSC Adv. 2015, 5, 2270322711.

[10] M. L. Contente, I. Serra, F. Molinari, R. Gandolfi, A. Pinto, D. Romano, Tetrahedron 2016, 72, 3974-3979.

[11] W. Adam, L. Blancafort, C. R. Saha-Möller, Tetrahedron: Asymmetry 1997, 8, 3189-3192.

[12] I. M. Ferreira, S. A. Yoshioka, J. V. Comasseto, A. L. M. Porto, RSC Adv. 2017, 7, 12650-12658.

[13] S. Conde, M. Fierros, M. I. Rodríguez-Franco, C. Puig, Tetrahedron: Asymmetry 1998, 9, 2229-2232.

[14] J. Hiratake, M. Inagaki, T. Nishioka, J. Oda, J. Org. Chem. 1988, 53, 6130-6133.

[15] J. Mangas-Sánchez, E. Busto, V. Gotor-Fernández, F. Malpartida, V. Gotor, J. Org. Chem. 2011, 76, 2115-2122.

[16] L. H. Andrade, L. P. Rebelo, C. G. C. M. Netto, H. E. Toma, J. Mol. Catal. B: Enzym. 2010, 66, 55-62.

[17] T. Itoh, Y. Matsushita, Y. Abe, S. H. Han, S. Wada, S. Hayase, M Kawatsura, S. Takai, M. Morimoto, Y. Hirose, Chem. Eur. J. 2006, 12 9228-9237.

[18] S. M. Lystvet, B. H. Hoff, T. Anthonsen, E. E. Jacobsen, Biocatal. Biotransform. 2010, 28, 272-278.

[19] E. Fuglseth, T. Anthonsen, B. H. Hoff, Tetrahedron: Asymmetry 2006, 17, 1290-1295.

[20] A. Träff, K. Bogár, M. Warner, J. E. Bäckvall, Org. Lett. 2008, 10, 48074810.

[21] M. Kapoor, N. Anand, K. Ahmad, S. Koul, S. S. Chimni, S. C. Taneja, G. N. Qazi, Tetrahedron: Asymmetry 2005, 16, 717-725.

[22] A. Kamal, M. Sandbhor, K. V. Ramana, Tetrahedron: Asymmetry 2002 13, 815-820.

[23] K. -W. Kim, B. Song, M. -Y. Choi, M. -J. Kim, Org. Lett. 2001, 3, 15071509.

[24] F. Campos, M. P. Bosch, A. Guerrero, Tetrahedron: Asymmetry 2000, 11, 2705-2717.

[25] O. Pàmies, J. -E. Bäckvall, J. Org. Chem. 2002, 67, 9006-9010.

[26] T. Ema, N. Ura, M. Yoshii, T. Korenaga, T. Sakai, Tetrahedron 2009, 65, 9583-9591.

[27] A. C. L. M. Carvalho, T. S. Fonseca, M. C. Mattos, M. C. F. Oliveira, T L. G. Lemos, F. Molinari, D. Romano, I. Serra, Int. J. Mol. Sci. 2015, 16, 29682-29716. 
[28] T. S. Fonseca, M. R. Silva, M. C. F. Oliveira, T. L. G. Lemos, R. A. Marques, M. C. Mattos, Appl. Catal., A 2015, 492, 76-82.

[29] A. Zaïdi, M. Merabet-Khelassi, L. Aribi-Zouioueche, Catal. Lett. 2015, 145, 1054-1061.

[30] R. Ding, Y. He, X. Wang, J. Xu, Y. Chen, M. Feng, C. Qi, Molecules 2011, $16,5665-5673$
[31] A. Hoz, H. Blasco, A. Díaz-Ortiz, J. Elguero, C. Foces-Foces, A. Moreno, A. Sánchez-Migallón, G. Valiente, New J. Chem. 2002, 26, 926-932.

[32] M. S. Ferreira, J. D. Figueroa-Villar, Quim. Nova 2015, 38, 233-236.

[33] T. Janeczko, M. Dymarska, E. Kostrzewa-Susłow, Int. J. Mol.Sci. 2014, $15,22392-22404$.

[34] A. A. Plentl, W. T. Kelly, Anal. Biochem. 1966, 17, 397-412.

[35] T. Masuda (Pola Pharma Inc., Nihon Nohyaku Co., Ltd.) WO 2014041708, 2014 [Chem. Abstr.]. 
Entry for the Table of Contents (Please choose one layout)

Layout 1:

\section{FULL PAPER}

Text for Table of Contents

Author(s), Corresponding Author(s)*

Page No. - Page No.

Title

Layout 2:

\section{FULL PAPER}

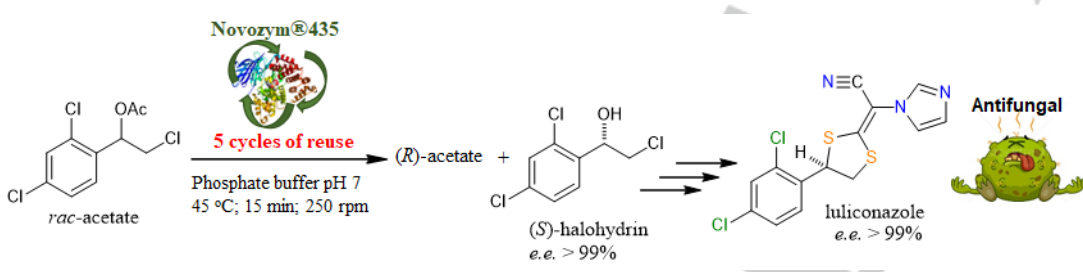

A new approach based on biocatalysis was developed for the production of the potent antifungal luliconazole. The lipase Novozym $435^{\circledR}$ proved to be a robust biocatalyst in the key step involving the preparation of an enantiomerically pure $\beta$-halohydrin in only $15 \mathrm{~min}$ of reaction. The enzyme was reused in up to 5 reaction cycles with maintenance of high values of activity and selectivity. After a few more steps, luliconazole was obtained in good yield and enantiomeric excess.
Thiago de S. Fonseca, Lara D. Lima, Maria da C. F. de Oliveira, Telma L. G. de Lemos, Davila Zampieri, Francesco Molinari, Marcos C. de Mattos ${ }^{*}$

\section{Page No. - Page No.}

Luliconazole via biocatalytic process 